\title{
Prezi-based Learning Video: Learning Media Validity and Feasibility
}

\section{Putu Gede Bagus Tedja Divayuda1*, I Made Citra Wibawa², Ni Wayan Rati}

1,2,3 Universitas Pendidikan Ganesha, Singaraja, Indonesia

\section{ART ICLE I N F O}

Article history:

Received March 20, 2021

Revised March 21, 2021

Accepted July 12, 2021

Available online August 25, 2021

Kata Kunci:

Tema Lingkungan Sahabat Kita, Prezi

Keywords:

Our Friend's Enviroment

Themes, Prezi

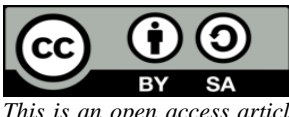

This is an open access article under the CC BY-SA license.

Copyright (C) 2021 by Author. Published by Universitas Pendidikan Ganesha.

\begin{abstract}
A B S T R A K
Penelitian ini didasari dengan rendahnya perhatian peserta didik terhadap pelaksanaan pembelajaran yang menggunakan aplikasi powerpoint sehingga menimbulkan kurangnya pemahaman peserta didik dan menyebabkan pengulangan dalam penjelasan materi pembelajaran yang disampaikan oleh pendidik. Tujuan penelitian ini ialah menghasilkan produk media video pembelajaran menggunakan prezi untuk peserta didik kelas V SD pada Tema Lingkungan Sahabat Kita Subtema Usaha Pelestarian Lingkungan yang valid. Jenis penelitian ini yakni penelitian pengembangan (Research and Development) yang dilaksanakan dengan model ADDIE. Pada Tahap Implementation (Implementasi), uji produk media video pembelajaran yang melibatkan peserta didik tidak dilaksanakan karena kondisi pandemi Covid-19. Metode pengumpulan data yang dipakai yakni berupa instrumen penilaian. Subjek penelitian ini adalah dua pakar isi mata pelajaran dan dua pakar media pembelajaran. Teknik yang digunakan dalam melakukan analisis data pada uji validitas media video pembelajaran menggunakan prezi ialah rumus Mean, rumus menghitung presentase dari masing-masing subjek, dan rumus presentase keseluruhan subjek. Hasil validitas isi mata pelajaran yang dilakukan oleh dua pakar isi mata pelajaran memeroleh hasil presentase total sebanyak 94,53\% dengan kualifikasi sangat baik. Hasil validitas media video pembelajaran yang dilakukan oleh dua pakar media pembelajaran memeroleh hasil presentase total sebanyak 95,83\% dengan kualifikasi sangat baik. Dengan demikian, dapat disimpulkan bahwa media video pembelajaran menggunakan prezi yang dikembangkan telah valid, sehingga layak dipakai untuk menunjang proses pembelajaran pada Tema Lingkungan Sahabat Kita Subtema Usaha Pelestarian Lingkungan Kelas V SD.
\end{abstract}

A B S T R A C T

This research was conducted based on students' low attention toward the implementation of learning using powerpoint so that it made the students lack of understanding and it caused the repetitive explanation of learning materials delivered by educators. This research aimed to produce a learning video media product using Prezi for fifth grade elementary school students on the Environmental Theme of Sahabat Kita, a valid sub-theme of Environmental Preservation Efforts. The type of this research was research and development carried out using ADDIE model. In the Implementation Phase, the test of learning video media products involving students was not carried out due to the Covid-19 pandemic conditions. The method of data collection was in the form of an instrument. The subjects of this study were two content subjects and two learning media experts. The technique used in conducting data analysis on the validity test of learning video media using Prezi was the Mean formula, calculating the percentage of each subject, and the overall percentage formula for the subject. The results of subject content validity conducted by two subject content experts obtained a percentage of $94.53 \%$ with very good qualifications. The results of the validity of learning video media conducted by two learning media experts obtained a percentage of $95.83 \%$ with very good qualifications. Thus, it can be said that the learning video media using Prezi that has been developed is valid, so it is feasible to be used to support the learning process on the Environmental Theme of Sahabat Kita, the Sub-theme of Environmental Preservation for fifth grade elementary school students.

\section{INTRODUCTION}

COVID-19 pandemic is a very heartbreaking disaster for all people on earth, so that all segments of human life on earth are starting to be disrupted and one of the areas that greatly hinders the field of education, causing all countries to decide to temporarily close educational activities in schools, higher education, universities, and so on (Aji, 2020 ; Robandi \& Mudjiran, 2020). Indonesia has also closed the educational institutions to protect citizens from staying at home. Even though educational institutions have been temporarily closed, teaching and learning activities should not stop so that solutions are required to continue education (Herliandry et al., 2020 ; Pakpahan \& Fitriani, 2020). The solution to continuing education is online learning which was originally in the form of face-to-face learning (Supiani 
et al., 2020). Online learning is a learning process that can be carried out with the help of websites or applications and interactive internet connectivity to create positive interactions between educators and students during learning (Lubis \& Dasopang, 2021). Online learning is focused on the accuracy and foresight of students in receiving material in order to process the information presented online according to their needs (Putria et al., 2020). One of the components discussed to help support online learning is that learning media can help educators grow the potential by presenting the creative, interesting, and fun learning materials for students. Learning media serves as a suggestion to convey material so that students may have the same perception (Untari et al., 2017). Learning media consists of various types of components depending on the wishes of the user and can produce students to learn in outline, learning media can be classified into three major groups, namely audio media, visual media, and audio-visual media (Saruruddin et al., 2019). One of the three major classifications of learning media is audio-visual or video media. Audio-visual or video media is a set of components that can display images and sound at the same time directly and simultaneously (Yunita \& Wijayanti, 2017).

However, the online learning that has been carried out in elementary schools is indeed a solution in the Covid-19 outbreak which of course the implementation of this learning cannot be separated from problems that cause various obstacles (Saefulmilah \& Saway, 2020). This condition can cause online learning problems at SD Negeri 3 Mengwi which have been known during the Online-based Field Introduction and observations obtained that they did not pay attention to the powerpoints made by educators. The educators only used Microsoft PowerPoint for explaining the learning materials, and students frequently asked questions about learning materials that have been explained previously. The use of Microsoft PowerPoint is good because it is a laptop's component, but the weaknesses of Microsoft PowerPoint as a learning support is that it cannot collaborate and work together in preparing the flow of learning materials and materials that are presented sequentially or linearly, so that the presentation of learning material seems boring and monotonous for students (Purnomo, 2020). Based on this, it can be said that the online learning carried out at SD Negeri 3 Mengwi using a Microsoft PowerPoint application as a means to help explain and emphasize learning materials is less than optimal, This has a negative impact on students including; a. misunderstandings between educators and students frequently occur during the presentation of learning objectives and learning materials, so educators must repeat learning materials which result in difficulties in completing learning objectives (Kahfi, 2020); b, Repeated explanations of material by educators can cause problems with the limited quota of students in online learning and the ability of parents in explaining the learning materials (Muffarohah \& Rukmi, 2020; Maryatun, 2020); c, Students have problems using information technology or IT and problems with internet connections, especially students living in rural areas (Bahasoan et al., 2020).

Starting from this problem, an alternative to delivering digital material using the Prezi application is required as a learning video media. The use of Prezi application to support learning has been developed with a study entitled Development of Learning Media Using Prezi in Thematic Learning of the Theme of Objects in the Environment Around the Fifth Grade Students by obtaining decent results and can be used as an alternative to thematic learning media for the fifth grade of elementary school (Martono, 2015). Supported by the experience and results, the development of learning video media using Prezi can be used as an alternative and interesting to support learning, has the potential to foster student interest in listening to learning, and can be downloaded to make it easier for students to learn without a quota so it has the potential to optimize the achievement of learning objectives, especially in grade 5 . The aforementioned statement is supported by statement that the Prezi application has advantages over other applications and mentions 16 advantages of Prezi applications including a, provide more interesting and innovative presentation style; b, provide dynamic presentation; c, accessible through email account; $d$, stimulate ideas and creativity of the user; e, software or complete website; f, provide many examples of presentations in the library of Prezi application; g, provide tutorials for making presentations; $h$, the application can be accessed for free; i, can be used to make presentations online/offline; j, Prezi application space of $100 \mathrm{MB}$; $\mathrm{k}$, each presentation is marked with a Prezi logo; l, presentation performance can be improved by prepayment; $m$, the presentation results that have been made can be used directly online and downloaded for offline viewing; n, can insert sound, powerpoint, and so on, o, presentations possible in one frame individually or in groups; and p, one of the graphic elements can help the user to present information in a structured manner (Eliyana 2014; Wardani, 2015). Prezi media focuses on one area of the slide called the virtual canvas, so users can explore parts of the canvas from the largest to the smallest (zooming User Interface) about the concept so that it remains clearly visible in order to facilitate the delivery of learning materials (Wijayanti, 2019; Wahyudi et al., 2019).

The positive impact obtained from the Prezi application is that the Prezi application can zoom in and out of different items in each focus of different learning materials so it can show the relationship between the interesting points of view for students, and the learning process becomes fun and passionate 
for students and educators (Arifiya, 2020). Prezi application can be a learning video media that certainly supports learning materials. The focus of the developed learning material is on the enviromental theme of Sahabat Kita, the sub-theme of environmental conservation efforts with the topic of the influence of economic activities on the welfare of the community and respecting the economic activities of others from the Social Sciences subjects in learning 3 and 4 to achieve the concept of the context of Sahabat Kita environmental theme, the sub-theme of environmental conservation efforts. This study aimed to describe the validity of the development of learning video media using Prezi for the environmental theme of Sahabat Kita in grade 5 at SD Negeri 3 Mengwi, with the hope that education will continue even though it is faced with various problems that can be overcome by utilizing learning video media along with a platform to meet face to face and discuss virtually by utilizing the ability of educators to provide creative and maximum learning for students. Thus, using Prezi as learning video media, educators can train creativity and develop innovations in making media, especially learning video media so that learning has the potential to be fun, interesting, and meaningful from previous learning for students.

\section{METHOD}

The development model used in this study was the ADDIE development model. This development model involved 5 stages, namely Analysis, Design, Development, Implementation, and Evaluation. However, online learning caused more face-to-face learning through the zoom platform/google meet/and so on, so the research was carried out without the Implementation stage. The types of data that would be collected through the implementation of formative evaluations were categorized into two parts, namely the first data, qualitative data on the design of the development of learning video media using Prezi using the ADDIE development model on the environmental theme of Sahabat Kita, the sub-theme of environmental preservation for fifth grade students at SD Negeri 3 Mengwi. Data obtained from quantitative data; and the second data, quantitative results, namely the closed questionnaire method which had previously been given to content experts in learning subjects and learning media experts. The validation design carried out in this learning video media development research, in the form of flash data which would be tested later for its validity level, through analysis of trial activities carried out through evaluation from experts (Expert Judgment), subject content experts, and learning media experts who had been determined based on the consideration of educational criteria, experience, expertise, availability of time, and energy to provide the data needed for the product before being tested with students.

The subject of validation in the development of learning video media used Prezi with experts who would evaluate with the other two subject content experts and learning media experts from the Primary School Educator Education Study Program at Ganesha University of Education. The object of validation in this development research was Prezi as the learning video media on the theme of the environment, Sahabat Kita, the sub-theme of environmental preservation, the topic of the influence of economic activities on people's welfare and respecting the economic activities of others. The data were collected through the document recording method which was carried out by making reports of the stages that had been carried out in the process of developing learning video media using Prezi. Document recording began in the analysis phase at SD Negeri 3 Mengwi in the form of a learning process, notes from interviews, and observations; and the questionnaire method is a way of obtaining by communicating the data sources. The questionnaire method was used to measure the feasibility of a product that had been done well with evaluations from subject content experts and learning media experts. The development of research instrument that would be used to collect information was in the form of a Likert scale instrument, a psychometric scale that is commonly used in questionnaires and is widely used in survey research. Likert scale tips were used to facilitate the process of calculating the results of the survey being tested. The solution to the given problem, the respondent could choose one of the options given. Generally, 4 preference scales were provided to confirm the expert's accuracy in choosing according to the results of the instructional video media using Prezi with the choice of very appropriate (SS) being given a score of 4, appropriate (S) being given a score of 3 , not suitable (TS) being given a score of 2 , and also strongly disagree appropriate (STS) was given a score of 1 (Firmansyah et al., 2016). The Likert scale instrument was given to subject content experts and learning media experts to assess the validity of the learning video media using the developed Prezi. To ensure that validity can run well, activities would be carried out, namely compiling grid tables, consulting with supervisors, making and writing instruments, and testing the validity of learning video media with experts. The developed instrument grid was structured with reference to five aspects of format, content, language, practicality, and effectiveness (Maryuliana et al., 2016). The five aspects were made in the form of an instrument based on the criteria for each aspect, namely: the format aspect criteria included color, writing, letters, and layout; the criteria for the content aspect included the suitability of the material with the indicators, the material, the completeness of the 
material, and the attractiveness of the material in the media; the criteria for language aspects included the use of language, language standards, and sentence effectiveness; criteria for practical aspects related to the use of instructional video media; and the criteria for the effective aspect are also related to the use of learning media using Prezi (Monika, 2014). Tables 01 and 02 below presented the subject content validation grids and the learning video media validation grids using Prezi.

Table 1. Table of Specification of Subject Content Validation on Video Learning Media Using Prezi

\begin{tabular}{|c|c|c|c|c|}
\hline No & Aspect & Indicator & Total Item & $\begin{array}{l}\text { Number of } \\
\text { Item }\end{array}$ \\
\hline \multirow{3}{*}{1} & \multirow{3}{*}{ Format Aspect } & Punctuation Usage & 1 & 1 \\
\hline & & Systematicness of Material Presentation & 1 & 2 \\
\hline & & Relation of Learning Materials & 4 & $3,4,5$, dan 6 \\
\hline \multirow{4}{*}{2} & \multirow{4}{*}{ Content Aspect } & $\begin{array}{l}\text { Suitability between indicator and basic } \\
\text { competency in which supported by } \\
\text { learning video media using prezi }\end{array}$ & 1 & 7 \\
\hline & & $\begin{array}{l}\text { Suitability between indicator and learning } \\
\text { material in which supported by learning } \\
\text { video media using prezi }\end{array}$ & 1 & 8 \\
\hline & & $\begin{array}{l}\text { Suitabilty between learning purpose and } \\
\text { learning material in which supported by } \\
\text { learning video media using prezi }\end{array}$ & 1 & 9 \\
\hline & & $\begin{array}{l}\text { Completeness of information from learning } \\
\text { materials contained in learning video } \\
\text { media using prezi }\end{array}$ & 1 & 10,11 , and 12 \\
\hline \multirow{3}{*}{3} & \multirow{3}{*}{$\begin{array}{l}\text { Language } \\
\text { Aspect }\end{array}$} & $\begin{array}{l}\text { Using sentence with correct Enhanced } \\
\text { Spelling System }\end{array}$ & 1 & 13 \\
\hline & & $\begin{array}{l}\text { Using correct term depend on the learning } \\
\text { material }\end{array}$ & 1 & 14 \\
\hline & & Effectiveness of Sentences & 1 & 15 \\
\hline 4 & $\begin{array}{l}\text { Effectiveness } \\
\text { Aspect }\end{array}$ & $\begin{array}{l}\text { Learning material suitable with students' } \\
\text { characteristic }\end{array}$ & 1 & 16 \\
\hline
\end{tabular}

Table 2. Table of Specification of Learning Media Validation on Video Learning Media Using Prezi

\begin{tabular}{|c|c|c|c|c|}
\hline No & Aspect & Indicator & Total Item & $\begin{array}{c}\text { Number of } \\
\text { Item }\end{array}$ \\
\hline \multirow{7}{*}{1} & \multirow{7}{*}{ Format Aspect } & Interesting cover & 1 & 1 \\
\hline & & Suitable font size & 1 & 2 \\
\hline & & Well organized layout & 1 & 3 \\
\hline & & Interesting media & 1 & 4 \\
\hline & & Color balance & 1 & 5 \\
\hline & & Quality of writing, music, and image & 3 & 6,7, dan 8 \\
\hline & & $\begin{array}{l}\text { Video learning media using prezi suitable } \\
\text { with material presentation and music }\end{array}$ & 1 & 9 \\
\hline \multirow{3}{*}{2} & \multirow{3}{*}{$\begin{array}{l}\text { Language } \\
\text { Aspect }\end{array}$} & Language standard by presenter & 1 & 10 \\
\hline & & Convenient language & 1 & 11 \\
\hline & & Sentence effectiveness & 1 & 12 \\
\hline \multirow{2}{*}{3} & \multirow{2}{*}{ Practical Aspect } & $\begin{array}{l}\text { Video learning media using prezi easy to } \\
\text { access online }\end{array}$ & 1 & 13 \\
\hline & & $\begin{array}{l}\text { Video learning media using prezi easy to } \\
\text { use offline }\end{array}$ & 1 & 14 \\
\hline 4 & $\begin{array}{l}\text { Effectiveness } \\
\text { Aspect }\end{array}$ & $\begin{array}{l}\text { Learning video media using prezi suitable } \\
\text { with students' characteristic }\end{array}$ & 1 & 15 \\
\hline
\end{tabular}

The analytical methods and techniques used in this development research were qualitative descriptive statistical analysis techniques and quantitative descriptive statistics. Statistical analysis used to process the results of a review of data, suggestions, and criticisms made by learning media experts and learning content experts on the developed media, aimed to classify the obtained information based on qualitative data in the form of suggestions and criticisms of the results of the analysis as an effort to 
improve the videos learning media using prezi. Quantitative statistical analysis was used to process data in the form of numbers obtained in the form of numbers/scores through the assessment of learning media assessments developed for educators and lecturers as experts. The assesment of video learning media using Prezi was conducted after obtaining data. The obtained data will be weighed individually and calculated the average score using the Mean formula (Sukardiyono \& Ernawati, 2017). The average score had been obtained and then it would be converted using a conversion scale of 4 to determine the validity of the developed media. The scale 4 conversion used was presented in Table 3.

Table 3. Achievement Level Conversion with 4 Scale

\begin{tabular}{cc}
\hline Scroe Range & Category \\
\hline$M i>3,4$ & Very good \\
$2,8<M i \leq 3,4$ & Good \\
$2,2<M i \leq 2,8$ & Standard \\
$1,6<M i \leq 2,2$ & Poor \\
$M i>1,6$ & Very poor \\
\hline
\end{tabular}

The scale conversion 4 in Table 3 was obtained by using the calculation of the ideal mean (Mi) and ideal standard deviation (SDi) (Hamadi et al., 2018) modified Mi and SDi and followed by entering the results of Mi and SDi into the formula for the range of scores presented in Table 4. Then the percentage of results was calculated. Formula used to calculate the percentage of each subject was also used to calculate the percentage of the whole subject (Siddiq et al., 2020). To grow meaning in decision making regarding the feasibility of the product being developed, the provisions were used (Winarsih et al., 2019) which were presented in Table 5.

Table 4. Achievement Rate Conversion Calculation with 4 Scale

\begin{tabular}{cc}
\hline Score Range & Category \\
\hline$X \geq \mathrm{Mi}+1 . S D i$ & Very good \\
$M i+1 . S D>X \geq M i$ & Good \\
$M i>X \geq M i-1 . S D i$ & Poor \\
$X \geq \mathrm{Mi}-1 . S D i$ & Very poor \\
\hline
\end{tabular}

Table 5. Achievement Rate Conversion with 4 Scale

\begin{tabular}{ccl}
\hline Achievement Level & Qualification & \multicolumn{1}{c}{ Note } \\
\hline $81 \%-100 \%$ & Very good & No need revision \\
$66 \%-80 \%$ & Good & No need revision \\
$56 \%-65 \%$ & Poor & Need revision \\
$0 \%-55 \%$ & Very poor & Need revision \\
\hline
\end{tabular}

\section{RESULT AND DISCUSSION}

\section{Result}

First, the Analysis Phase. The results of the analysis of student needs can be a guide to the stages of problem solving that are currently happening at SD Negeri 3 Mengwi. It began with content analysis, which was related to the competencies that must be achieved by students including Core Competencies, Basic Competencies and Indicators, and Learning Objectives. The achieved core competencies were understanding the factual knowledge at a basic level by observing based on curiosity about themselves, God's creatures and their activities, as well as objects they encounter at home, at school, and at the playground. Basic Competencies and Indicators to be achieved are presented in Table 6. The learning objectives that would be completed by students were done through watching videos. Through watching videos, students were able to analyze the influence of economic activities on the level of community welfare correctly, and students were able to correctly analyze the production, distribution, and consumption processes of the clothing business. Furthermore, a facility/environment analysis with field observations accompanied by interviews and document recording with fifth grade educators which stated that the learning support was in the form of a laptop operated by the educator and the implementation of the social studies learning process which was only explained during the online face-to-face 
implementation and could not be downloaded, making it difficult for students to listen fluently in social studies learning.

Table 6. Basic Competency and Indicator

\begin{tabular}{llll}
\hline No. & \multicolumn{1}{c}{ Basic Competency } & No. & \multicolumn{1}{c}{ Indicator } \\
\hline 3.3 & $\begin{array}{l}\text { Analyzing economics role as the } \\
\text { way to improve people's lives in the }\end{array}$ & $\begin{array}{l}\text { Analyzing the influence of economic activities } \\
\text { (production, distribution, and consumption) in } \\
\text { daily life. }\end{array}$ \\
$\begin{array}{l}\text { social and cultural fields to } \\
\text { strengthen unity and integrity of } \\
\begin{array}{l}\text { Indonesia and its relation to the } \\
\text { characteristic of space }\end{array}\end{array}$ & & $\begin{array}{l}\text { Analyzing the proses of production, distribution, } \\
\text { and consumption of clothing products. }\end{array}$ \\
\hline
\end{tabular}

Second, the stage of designing learning video media using Prezi began to determine Basic Competencies and Indicators in Social Studies subjects for grade 5 even Semester. Furthermore, scenarios were made to pay attention to and consider various criteria for learning video media and making designs that aim to optimize the determination of the layout. The results of the design stage of learning video media using Prezi are presented in feature 1.
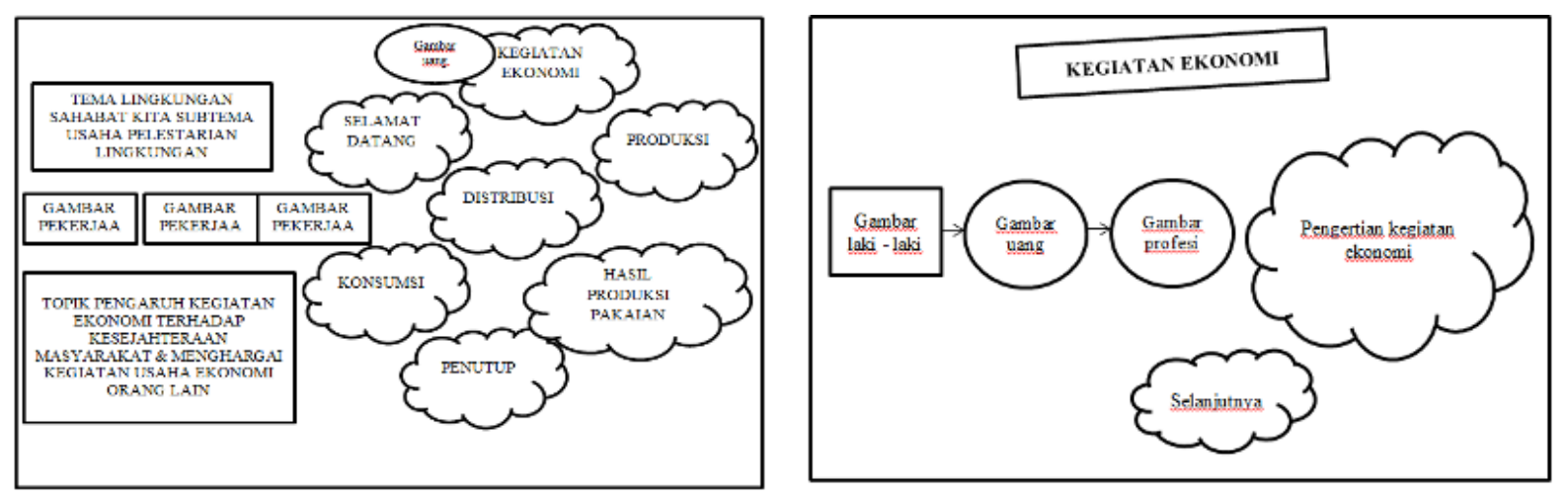

Feature 1. Video Learning Media Design Stage Using Prezi

Third, the stage of developing video learning media using Prezi was carried out to collect learning materials or themes such as images, text, illustrations, audio, and animations. After all the supporting aspects that had been collected would be combined into one complete learning video product using the Prezi application as the main program. The results of the development stage of video learning media using Prezi are presented in feature 2.
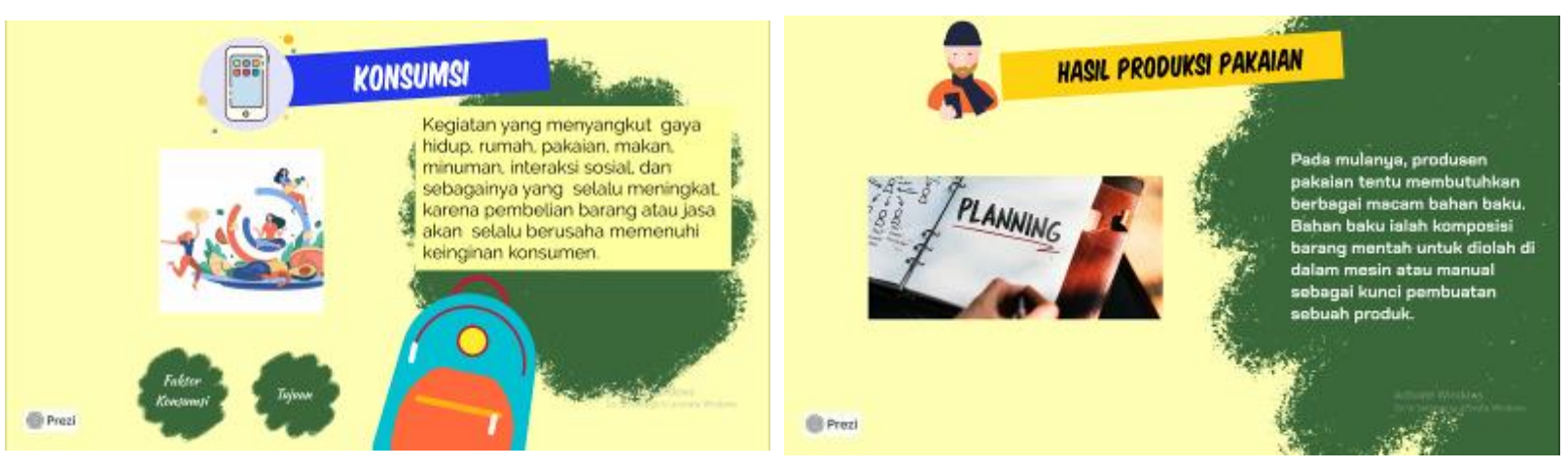

Feature 2. Video Learning Media Development Stage Using Prezi

Fifth, the Evaluation Phase, an assessment was carried out to validate the products that had been made through expert tests. The product validity test aimed to test the level of product consistency that had been done. This product test consisted of subject content experts and learning media experts. The purpose of the validity test was to make the video learning media that had been developed into an appropriate learning media, can attract learning intentions, and has the potential to improve student learning outcomes. Based on the results of the feasibility assessment of the subject matter content by the 
two subject matter experts above, the results of the assessment with an average score of 3.78 were obtained. In the conversion level of achievement with a scale of 4, the average score for the assessment of the content of the subjects was between the range of $(M i>3,4)$ which considered as a very good category. Furthermore, the results of calculating the feasibility of subject content in video learning media using Prezi with two subject matter experts are presented in Table 7.

Table 7. Percentage of Data Analysis Result of Feasibility Testing of Subject Content in Video Learning Media Using Prezi

\begin{tabular}{ccccc}
\hline No. & Subject & Validity Result & Qualification & Note \\
\hline 1 & Expert Test I Subject Content & $95,31 \%$ & Very good & No need revision \\
2 & Expert Test II Subject Content & $93,75 \%$ & Very good & No need revision \\
\hline & Total Percentage\% & $\mathbf{9 4 , 5 3 \%}$ & Very good & No need revision \\
\hline
\end{tabular}

Based on the table above, the total percentage was $94.53 \%$. After obtaining the percentage of the results of the two subject content expert tests, the percentage results would be converted together with the conversion table for the level of achievement of scale 4. Based on the percentage table, the expert test I was $95.31 \%$ and the expert test II was $93.75 \%$. The total percentage of the two expert tests as much as $94.53 \%$ was between the range of $81-100 \%$ which considered as a very good qualification with the addition of video learning media using Prezi. Based on the results of the feasibility assessment of learning media by two learning media experts, the results of the assessment were obtained with an average score of 3.83. In the conversion level of achievement with a scale of 4, the average score for the assessment of the content of the subjects was between the range $(M i>3,4)$ which considered as a very good category. Furthermore, the results of calculating the feasibility of video learning media using Prezi are presented in Table 8.

Table 8. Percentage of Data Analysis Result of Feasibility Testing in Video Learning Media Using Prezi

\begin{tabular}{ccccc}
\hline No. & Subject & Validity Result & Qualification & \multicolumn{1}{c}{ Note } \\
\hline 1 & Expert Test I Learning Media & $96,66 \%$ & Very Good & No need revision \\
2 & Expert Test II Learning Media & $95 \%$ & Very Good & No need revision \\
\hline & Total Percentage\% & $\mathbf{9 5 , 8 3 \%}$ & Very Good & No need revision \\
\hline
\end{tabular}

Based on the table above, the total percentage was $95.83 \%$. After obtaining the percentage of the results of the two subject content expert tests, the percentage results would be converted together with the conversion table for the level of achievement of scale 4. Based on the percentage table, expert I test was $96.66 \%$ and expert II test was $95 \%$. The total percentage of the two expert tests as much as $95.83 \%$ was between the range of $81-100 \%$ which considered as a very good qualification with the addition of video learning media using Prezi.

\section{Discussions}

In the analysis stage, the learning implementation was obtained in the order of Core Competencies, Basic Competencies, and Learning Objectives which were used to carry out the online learning process so that these three components are very important to measure the level of completeness of the learning process. This statement is supported by the results of research which stated that core competencies, basic competencies \& indicators, and learning objectives were a series of learning to obtain maximum results that direct the achievement of goals as a learning direction (Mansyur, 2020; Khairunnisa \& Jiwandono, 2020). The facilities used by educators during online learning were laptops which of course facilitated the process of class management by monitoring student attendance, and so on. Fulfilling the analysis stage, the Prezi application is needed because it offers a variety of learning experiences that are more interesting than conventional media so that it has the advantage of using an attractive visual display, both in terms of writing, color, audio, movement and video display (Zoebaidha, 2020 ; Rohman et al., 2021). Based on observations made during observation, the design stage would be planned to adjust to the needs in the field so that it was right on target of the usefulness of video learning media using Prezi.

At the Design stage, the preparation of Core Competencies, Basic Competencies and Indicators, Learning Objectives, Scenarios, and the design of video learning media began. The preparation of Core Competencies, Basic Competencies and Indicators, and Learning Objectives was carried out so that they were in accordance with the learning mastery that would be achieved by students according to the order of achievement. Scenarios were arranged to consider and to pay attention on various criterias for video 
learning media, both in terms of duration, use of music, and so on so that they were in accordance with the learning material (Fechera et al., 2012; Munawaroh et al., 2021). The design was structured to estimate and to optimize the layout of text, images, and so on from the learning material, so that the next stage was easier to realize. Furthermore, at the Development stage, it was carried out to realize the scenario and design. The next was developing visual and audio displays by presenting and emphasizing learning materials that were complete and in one video so that it became interesting and this also aimed to meet the eligibility criteria for video learning media by validating subject content experts and learning media experts so that the products that had been made are feasible to be used (Calorin, 2020). Next, the evaluation stage was carried out to obtain the level of product feasibility by using a questionnaire with two subject content experts and two learning media experts. This stage aimed to see whether the goal had been achieved or not by concluding the percentage of results from the questionnaire (Calorin, 2020). Thus, the feasibility of instructional video media is very important, because it fosters correction of misinformation that had been presented to students and so on, thereby it can reduce the negative impact of information received by students.

This study involved two subject content experts. Based on the results of a review from expert I, the content of the subjects was categorized as very good validity criteria. The data showed that it had met the indicators in terms of format, content aspects, language aspects, and effective aspects of developing subject products in video learning media using Prezi so that it was declared valid and feasible to use. The assessment was based on well-developed subject content validation. However, the development of this product had several weaknesses such as using more communicative sentences, not just informative sentences. Furthermore, the review results from the second expert of subject content obtained very good validity criteria. The data showed that it had met the indicators in terms of format, content aspects, language aspects, and effective aspects of developing subject products in video learning media using Prezi so that it was declared valid and feasible to use. The assessment was based on the validation of the content of the developed subjects from the good aspect. However, despite this, of course, the development of this product had several weaknesses such as the need to adjust the material displayed with audio.The overall review results from the second expert of subject content obtained very good validity criteria. The data showed that it had met the indicators in terms of format, content aspects, language aspects, and effective aspects of developing subject products in video learning media using Prezi so that it was declared valid and feasible to use. The assessment was based on well-developed subject content validation. However, the content of the subjects in video learning media using Prezi had been feasible to be used to support the learning process.

Furthermore, based on the results of a review from expert I of learning media obtained very good validity criteria. The data showed that it had met the indicators in terms of format aspects, language aspects, practical aspects, and effective aspects of product development of subject content in video learning media using Prezi so that it was declared valid and feasible to use. The assessment was obtained based on the validation of the content of the developed subjects that were good, but the presenter's voice required variations in intonation. Furthermore, the review results from the second expert of subject content obtained very good validity criteria. The data showed that it had met the indicators in terms of format, content aspects, language aspects, and effective aspects of developing subject products in video learning media using Prezi so that it was declared valid and feasible to use. The assessment was based on well-developed subject content validation, however, the the writing is not big enough and KD writing should be not cropped by Microsoft word. The overall results of the review from two learning media experts obtained very good validity criteria. The data showed that it had met the indicators in terms of format aspects, language aspects, practical aspects, and effective aspects of product development of subject content in video learning media using Prezi so that it was declared valid and feasible to use. Based on the results of the reviews that had been carried out, there are several corrective suggestions and comments. However, video learning media using Prezi had been feasible to be used to support the learning process. Thus, their research showed that Prezi media is feasible to use for developing lesson plans.

\section{CONCLUSION}

This study discussed about the video learning media using Prezi on the environmental theme of Sahabat Kita, a sub-theme with the topic of the influence of economic activities on people's welfare and respecting other people's economic business activities from Social Science subjects in learning 3 and 4 of fifth grade elementary school. The development of this video learning media used limited ADDIE development model because it did not not apply the Implementation stage. The results of the subject content validity test and the validity of the learning media were declared valid by the two subject content 
experts and the two learning media experts. Thus, based on these results, the product of video learning media using Prezi on the environmental theme of Sahabat Kita, a sub-theme with the topic of the influence of economic activities on people's welfare and respecting other people's economic business activities from Social Science subjects in learning 3 and 4 of fifth grade elementary school is feasible to use in the learning process.

\section{REFERENCES}

Aji, R. H. S. (2020). Dampak Covid-19 pada Pendidikan di Indonesia: Sekolah, Keterampilan, dan Proses Pembelajaran. Jurnal Sosial \& Budaya Syar-I, 7(5), 395-402. https://doi.org/10.15408/sjsbs.v7i5.15314.

Arifiya, N., Hartini, S., \& Syafa'atun. (2020). Pemanfaatkan Aplikasi Prezi di Lembaga Bimbingan Belajar GAMA UI Cabang Duren Tiga Jakarta Selatan. Jurnal Abdimas Siliwangi, 3(2), 238-244. http://dx.doi.org/10.22460/as.v3i2p\%25p.3754.

Bahasoan, A. N., Ayuandini, W., Mukhram, M., \& Rahmat, A. (2020). Effectiveness of Online Learning in Pandemic Covid-19. International Journal of Science, Technology \& Management, 1(2), 100-106. https: //doi.org/10.46729/ijstm.v1i2.30.

Calorin, L. L. (2020). Pengembangan Media Video Pembelajaran dengan Model ADDIE pada Materi Teknik Dasar Tendangan Pencak Silat Kelas VII SMP Negeri 4 Sukasada Tahun Pelajaran 2019/2020. Jurnal Kesehatan Jasmani Olah Raga, 5(2), 12-18. https://doi.org/10.36526/kejaora.v5i2.934.

Fauzia, A. \& Sakti, C. N. (2017). Pengembangan Media Pembelajaran dengan menggunakan Aplikasi Prezi pada Pokok Bahasan KD 3.5 Mendeskripsikan Bank Sentral, Sistem Pembayaran dan Alat Pembayaran dalam Perekonomian Indonesia di Kelas X IPS Al-Islam Krian Sidoarjo. Jurnal Pendidikan Ekonomi, 5(3), 1-5.

Fechera, B., Somantri, M., \& Hakim, D. L. (2012). Desain dan Implementasi Media Video Prinsip-Prinsip Alat Ukur Listrik dan Elektronika. Jurnal Invote, 8(2), 115-126. https://doi.org/10.17509/invotec.v8i2.6125.

Firmansyah, A., Hadiarti, D., \& Sartika, R. P. (2016). Pengembangan Instrumen Penilaian (Assesment) menggunakan Wondershare Quiz Creator pada Materi Konsep MOL Siswa Kelas X SMK Negeri 7 Pontianak. Jurnal Ilmiah Ar-Razi, 4(2), 1-10. http://dx.doi.org/10.29406/arz.v4i2.669.

Hamadi, A. A. L., Priyayi, D. F., \& Astuti, S. P. (2018). Pemahaman Guru terhadap Keterampilan Proses Sains (KPS) dan Penerapannya dalam Pembelajaran IPA SMP di Salatiga. Jurnal Pendidikan Sains \& Matematika, 6(2), 42-53. https://doi.org/10.23971/eds.v6i2.935.

Herliandry, L. D., Nurhasanah, Suban, M. E., \& Kuswanto, H. (2020). Pembelajaran pada Masa Pandemi Covid-19. Jurnal Teknologi Pendidikan, 22(1), 65-70.

Kahfi, A. (2020). Tantangan dan Harapan Pembelajaran Jarak Jauh di Masa Pandemi Covid 19. Dirasah: Jurnal Pemikiran \& Pendidikan Dasar Islam, 3(2), 137-154. https://stai-binamadani.e-journal.id.

Lubis, A. H. \& Dasopang, D. M. (2021). Online Learning During the Covid-19 Pandemic: How is it Implemented in Elementary Schools? Premiere Educandum: Journal of Basic Education and Learning, 11(1), 120 - 134. https://doi.org/10.25273/pe.v11i1.8618.

Mansyur, A. R. (2020). Dampak Covid-19 terhadap Dinamika Pembelajaran di Indonesia. Education and Learning Journal, 1(2), 113-123. http://dx.doi.org/10.33096/eljour.v1i2.55.

Martono, D. R. (2015). Pengembangan Media Pembelajaran Menggunakan Prezi pada Pembelajaran Tematik Tema Benda - Benda di Lingkungan Sekitar Siswa Kelas V SD. Universitas Muhammadiyah Malang.

Maryuliana, Subroto, I. M. I., \& Haviana, S. F. C. (2016). Sistem Informasi Angket Pengukuran Skala Kebutuhan Materi Pembelajaran Tambahan sebagai Pendukung Pengambilan Keputusan di Sekolah Menengah Atas Menggunakan Skala Likert. Jurnal Transistor Elektro dan Informatika (TRANSISTOR EI), 1(2), 1-12. http://dx.doi.org/10.30659/ei.1.1.1-12.

Monika, I. (2014). Uji Aktivitas Ekstrak Kencur terhadap Pengendalian Pertumbuhan Fusarium Oxysporum dan Implementasinya dalam Pembuatan Flipbook. Jurnal Pendidikan Dan Pembelajaran Khatulistiwa, 3(2), 1-14.

Muffarohah, L., \& Rukmi, A. S. (2020). Pengembangan Media Video Animasi Dua Dimensi untuk Keterampilan Menulis Puisi Siswa Kelas IV Sekolah Dasar. Jurnal Penelitian Pendidikan Guru Sekolah Dasar, 8(5), 861-871.

Prasetyo, W., \& Musafik, M. N. (2021). Analisis Kompetensi Guru, Fasilitas Belajar, dan Iklim Sekolah terhadap Hasil Belajar Siswa SMK Negeri 1 Jenangan Ponorogo. Jurnal Otonomi, 21(1), 111-117. https://doi.org/10.32503/otonomi.v21i1.1611. 
Purnomo, R., Fathurrozi, A., Prabandari, R. D., \& Sugiyatno. (2020). Kolaborasi Pembuatan Presentasi Menggunakan Aplikasi Prezi. Jurnal ABDIMAS (Pengabdian Kepada Masyarakat), 3(1), 51-58. https://doi.org/10.31599/jabdimas.v3i1.56.

Putria, H., Maula, L. H., \& Uswatum, D. A. (2020). Analisis Proses Pembelajaran dalam Jaringan (DARING) Masa Pandemi Covid-19 pada Guru Sekolah Dasar. Jurnal Basicedu, 4(4), 861-872. https: //doi.org/10.31004/basicedu.v4i4.460.

Saefulmilah, R. M. \& Saway, M. H. M. (2020). Hambatan-Hambatan pada Pelaksanaan Pembelajaran Daring di SMA Riyadhul Jannah Jalancagak Subang. Nusantara: Jurnal Pendidikan dan Ilmu Sosial, 2(3), 393-404. https://doi.org/10.36088/nusantara.v2i3.935.

Saruruddin, M., Hadi, Y. A., \& Burhanuddin. (2019). Pengembangan Media Audio Visual Menggunakan Macromedia Flash pada Mata Pelajaran IPS Tahun Pelajaran 2018/2019. Jurnal Didika: Wahana Ilmiah Pendidikan Dasar, 5(1), 24-31. http://garuda.ristekbrin.go.id.

Siddiq, Y. I., Sudarma, I. K., \& Simamora, A. H. (2020). Pengembangan Animasi Dua Dimensi pada Pembelajaran Tematik untuk Siswa Kelas III Sekolah Dasar. Jurnal EDUTECH, 8(2), 49-63. http://dx.doi.org/10.23887/jeu.v8i2.28928.

Sujarwo, A. \& Kholis, N. (2016). Pengembangan Media Pembelajaran Menggunakan Prezi pada Pelajaran Sistem Komputer di SMK Negeri 3 Budukan. Jurnal Pendidikan Teknik Elektro, 5(3), 879-901.

Sukardiyono, T. \& Ernawati, I. (2017). Uji Kelayakan Media Pembelajaran Interaktif Mata Pelajaran Administrasi Server. Jurnal Elinvo, 2(2), 204-210. https://doi.org/10.21831/elinvo.v2i2.17315.

Supiani, Rafidiyah, D., Yansyah, \& Nadia, H. (2020). Pengalaman Emosional Mahasiswa Program Doktor Asal Indonesia Belajar di Australia selama Pandemi COVID-19. Journal of International Students, 10(S3), 108-125. https://doi.org/10.32674/jis.v10iS3.3202.

Untari, M. F. A., Cahyadi, F., \& Budiningtyas, A. K. (2017). Pengembangan Media Lagu Matematikan dalam Pembelajaran di Kelas V Sekolah Dasar. Jurnal Mimbar Sekolah Dasar, 4(1), 92-105. https: //doi.org/10.23819/mimbar-sd.v4i1.6145.

Wardani, F. W. K. (2015). Perbandingan Hasil Belajar Siswa dalam Penerapan Problem Based Learning dengan dan Tanpa Dukungan Media Prezi pada Pembelajaran Akuntansi Kelas X di SMK Negeri 2 Nganjuk. Jurnal Pendidikan Akuntansi (JPAK), 03(03), 1-6.

Wijayanti, A. (2019). Pengembangan Media Pembelajaran Menulis Teks Negosiasi Berbasis Aplikasi Prezi Pada Siswa Kelas X SMA. Loa : Jurnal Ketatabahasaan Dan Kesusastraan, 14(1), 77-84.

Winarsih, Fatirul, A. N., \& Hartono. (2019). Pengembangan Buku Suplemen Seni Rupa Materi Penerapan Ragam Hias Pada Bahan Alam untuk Siswa Kelas VII SMP Negeri 2 Tanggulangin. Jurnal Mitra Pendidikan, 3(4), 632-643.

Yunita, D., \& Wijayanti, A. (2017). Pengaruh Media Video Pembelajaran terhadap Hasil Belajar IPA Ditinjau dari Keaktifan Peserta Didik. Sosiohumaniora: Jurnal Ilmiah Ilmu Sosial Dan Humaniora, 3(2), 153-160. http://dx.doi.org/10.30738/sosio.v3i2.1614.

Zoebaidha, S. (2020). Penggunaan Media Prezi dan Kahoot serta Pemberian Reward sebagai Upaya Meningkatkan Hasil Belajar Akuntansi. Jurnal Teknologi Pendidikan, 8(2), 213-233. http://doi.org/10.31800/jtp.kw.v8n2.p213--233. 